\title{
Climate change and the effect of increasing spring temperatures on emergence dates of the butterfly Apatura iris (Lepidoptera: Nymphalidae)
}

\author{
DENNIS DELL ${ }^{1}$, Tim H. SPARKS² and ROGER L.H. DENNIS ${ }^{3 *}$ \\ ${ }^{1} 8$ Viney Lane, Fairford Leys, Aylesbury, Bucks HP19 7GR, UK \\ ${ }^{2}$ NERC Centre for Ecology and Hydrology, Monks Wood, Abbots Ripton, Huntingdon, Cambridgeshire PE28 2LS, UK \\ ${ }^{3}$ Department of Biological and Molecular Sciences, Oxford Brookes University, Headington, Oxford OX3 0BP, UK \\ and The Manchester Museum (Entomology), Manchester University, Oxford Road, Manchester M13 9PL, UK
}

Keywords. Apatura iris, climate change, development time, phenology, Salix caprea, Switzerland, trends

\begin{abstract}
Data on pupation and emergence dates for the nymphalid Purple Emperor butterfly Apatura iris have been collected at Basel, Switzerland, between 1982 and 2002. The butterfly has been shown to emerge on average 9 (males) to 12 (females) days earlier per decade, 19 and 24 days earlier respectively over the study period. Emergence dates relate strongly to spring temperatures, particularly with daily maximum temperatures for the months March to May. Temperatures for these months have increased significantly during this period $\left(0.7^{\circ} \mathrm{C}\right.$ to $1.8^{\circ} \mathrm{C}$ per decade). Three factors suggest that the strongest influence of the rise in spring temperatures has been on late larval instar growth and development: (i) May temperatures dominate emergence date models and larvae are feeding faster and for longer periods during this month, (ii) Salix caprea flowering date, a surrogate for bud burst, is excluded in stepwise regression models with temperatures and years suggesting that tree phenology may be less important than temperature effects on later development, and (iii) convergence of female and male emergence dates over time points to limits on earlier feeding in protandrous males. A negative consequence observed with earlier emergence dates is lethal extra broods.
\end{abstract}

\section{INTRODUCTION}

Within recent years, long-term data sets have acquired an increasing importance owing to their potential value for tracking human-enhanced climatic changes (Houghton et al., 1996). A wide range of effects to natural systems has been attributed to current climatic warming, including: advancement of bud burst, flowering, fruiting and nesting (Fitter et al., 1995; Lechowicz, 1995; Crick et al., 1997; Colombo, 1998) and changes to development rates, physiology, morphology and migration (Jenni \& Kery, 2003; Dullinger et al., 2004). The impacts are far reaching, including latitudinal and altitudinal shifts in species ranges (Archaux, 2003; Cotton, 2003; Johnstone \& Chapin, 2003) and with consequences for whole communities and ecosystems (Skre et al., 2002; Georges \& Le Maho, 2003; Lemoine \& Bohning-Gaese, 2003; Travis, 2003). Despite the mounting evidence of the impact of global climatic change, long-term data on natural systems are sporadic and modelling change and impact therefore becomes necessary (e.g., Coppack \& Both, 2002; Malcolm et al., 2002; Higgins et al., 2003; Pearson \& Dawson, 2003). In order to predict future responses of organisms to climate changes, we first need to know how species have responded to climate change in the past. Thus, where long or medium term data exist they fulfil an important role in testing predictions and for building a composite picture of the impact of climatic changes on ecosystems (Harrington et al., 1999).
Butterflies provide particularly sensitive and conspicuous indicators of climatic and environmental changes (Dennis, 1993). As with most poikilothermic animals, both development and activity are closely influenced by climatic factors, particularly temperatures, and short generation times allow changes to be determined over relatively short time scales. Butterfly phenology is known to be sensitive to climatic changes; emergence dates, flight periods and number of broods have all been related to trends in warming over the past 20 years or more (Pollard \& Yates, 1993; Sparks \& Yates, 1997; Roy \& Sparks, 2000; Stefanescu et al., 2003). Dennis (1993) predicted a theoretical loss/gain of five species of butterfly per $10-30 \mathrm{~km}^{2}$ in the UK for every $1^{\circ} \mathrm{C}$ change in mean summer temperatures. And, climate change is now known to affect population sizes and species ranges (Pollard \& Yates, 1993; Hill et al., 1999; Parmesan et al., 1999). Pollard (1988) identified a powerful link between temperatures and population size; warm dry summers increase butterfly abundances. Most of the studies above have been done in Western Europe on species with herbaceous hostplants. Far less is known of the response for species whose larvae feed on shrubs and trees, and sufficient data from continental areas have yet to accrue to allow comparative analyses.

Here, we explore emergence dates for the high woodland butterfly Purple Emperor Apatura iris (Linnaeus) over a 21-year period from a central continental location in Switzerland. We ask a number of specific questions:

\footnotetext{
* Corresponding author: 4 Fairfax Drive, Wilmslow, Cheshire SK9 6EY, UK, e-mail: rlhdennis@aol.com
} 
Are emergence dates sensitive to changes in temperatures when the organism is developing? Are there systematic changes (trends) in emergence dates and, if these exist, do these relate to systematic changes in temperatures? What, if any, are the consequences of increasingly early emergence date for the butterfly?

\section{MATERIAL AND METHODS}

\section{Status and life cycle of Apatura iris}

As a tree top species Apatura iris is rarely recorded in transect data sets (Pollard \& Yates, 1993). It is also known to be declining in western and central Europe (Asher et al., 2001; van Swaay \& Warren, 1999)

Adult $A$. iris are univoltine and fly in June and July. Eggs are laid on sallows Salix caprea (L.) in shady positions along the rides or edges of woods. Development of $A$. iris larvae in the period prior to hibernation in November is slow; larvae attain their second instar and usually achieve a maximum length of 10 $\mathrm{mm}$. This contrasts starkly with the post hibernation period (March-May), when they almost quadruple in size in just six weeks; larvae feed by day and increase their feeding periods as they mature, by length as well as by frequency (Willmott, 1990). Larvae change colour on renewing activity from grey/brown, believed to be winter camouflage (Heslop et al., 1964) to bright green matching the colour of young $S$. caprea leaves. Pupation takes place during the last two weeks of May. The time between a larva moving to the underside of the leaf and the moment of pupation lasts from three to five days.

\section{Study area, breeding programme and phenological monitoring}

Eggs and early instar larvae were collected from a single population during July until October, 1982 to 2002 , in woodland close to Basel, Switzerland $\left(47.33^{\circ} \mathrm{N}, 7.36^{\circ} \mathrm{E}\right.$, altitude $380 \mathrm{~m}$ a.s.1.). A record was made of the numbers of eggs and larvae occurring in the area in which they were found so that a measure of population density could be made. Population density of the adults is difficult to determine as they tend to occupy tree tops. The larvae were bred on $S$. caprea in a nearby isolated suburban garden situation (278 $\mathrm{m}$ a.s.1.). $S$. caprea bushes were planted for the purpose of the study; their dimensions were managed to achieve a wide canopy ( $2.5 \mathrm{~m}$ high, $2 \mathrm{~m}$ wide), tapering down towards the ground, so that the leaves of the lower branches, used by the larvae, were shaded.

Larvae were retained in vials, outside, and in a shaded position, until the first week in September. $S$. caprea leaves were renewed every three to four days. The vials were carefully cleaned and dried on the inside every three days. At the beginning of September the second instar larvae were transferred to the leaves of a growing $S$. caprea bush in the garden. Only branches low down on the bush, facing north or north-east and in the shade, were used for the transfer in order to avoid exposing the larvae to the afternoon sun. The branches containing the larvae were enclosed in small mesh nylon netting. Before transferring larvae to a branch, the leaves and branches were very carefully examined for predatory insects and these were all removed. It was not usually necessary to carry out any further transfers before hibernation (November). Hibernation takes place in one of three positions: either on a bud, on the inside of the netting, or on a leaf. Most of the leaves fall from the branch to the bottom of the net, and the larvae find their way back to fresh leaves in spring. On renewing activity (March) larvae move onto leaves even before they have unfurled properly and may feed on buds before they have opened. As growth was depleted, they were moved onto new branches about every ten days until pupation.

Dates were recorded of pupation and emergence (days from April 30 in any year). The occurrence of parasitisation was also recorded. Climatic data (monthly mean and maximum temperatures) for Basel were obtained from The Swiss Meteorological Institute (MeteoSchweiz). No data for S. caprea phenology were available for Switzerland or nearby France. However, data on flowering of $S$. caprea (days from January 1) were available for 14 sites in south west Germany (within $47.36-48.54^{\circ} \mathrm{N}, 7.36$ $9.42^{\circ} \mathrm{E}$, mean altitude $398 \mathrm{~m}$ ) from Deutscher Wetterdienst. Flowering precedes bud burst and is here treated as a surrogate for bud burst timing; both are influenced by sap rising and are closely correlated in data for 16 years from the border counties of Hereford and Worcester in western England $(\mathrm{r}=0.84, \mathrm{P}<$ 0.001) (T.H. Sparks, unpubl. data).

For adult emergence date to relate to increasing temperatures with climate change, several outcomes are hypothesised:

(1) First, emergence date should become significantly earlier with time (years).

(2) Second, emergence dates should correlate strongly with monthly temperature changes most likely to influence development rates and timing.

(3) Third, temperatures should significantly increase, during the same period, for months when development is likely to be affected; a mismatch for months would suggest that either the model determined for development timing is wrong or that there is no effect of any climate change on emergence.

Potential explanatory variables included maximum temperatures for the months preceding hibernation (July to October) and for months during late hibernation, renewed activity, growth and development (February to June). Two other variables were entered into equations to test for population and sampling artefacts. The probability of detecting early emergences potentially increases with increasing population size (Thomas, 1985), there being more individuals to observe and greater potential genetic variability available. Owing to the difficulty of recording adults in the woodland canopy, this is based on the density of early stages found in the source woodlands. As the numbers of individuals bred each year were small and variable, sampling artefacts were tested by entering numbers bred into regression equations.

\section{Data processing and statistical tests}

All variables were checked for normality; no transformations proved necessary. Correlations were determined using Pearson's $\mathrm{r}$ and comparisons by applying pairwise $\mathrm{t}$ tests. Gamma, a non parametric association measure, was used for counts of parasitism with a large number of ties (Goodman \& Kruskal, 1972). Relationships between emergence date and climatic data (mean monthly maximum temperatures) were analysed using stepwise linear regression. Maximum temperatures were used rather than mean temperatures as they better describe conditions when larvae are developing during the day. As the data for emergence dates are means based on a variable number of records, weighted regression which places greater emphasis on those results based on larger numbers of observations was used (Draper \& Smith, 1981). Residuals were examined for model adequacy and emergence dates tested for autocorrelation. All analyses were conducted in STATISTICA (Statsoft, 1999).

\section{RESULTS}

\section{Phenology}

From 274 eggs and 476 larvae, 107 male and 96 female adult $A$. iris emerged (27\%). Females were missing from 


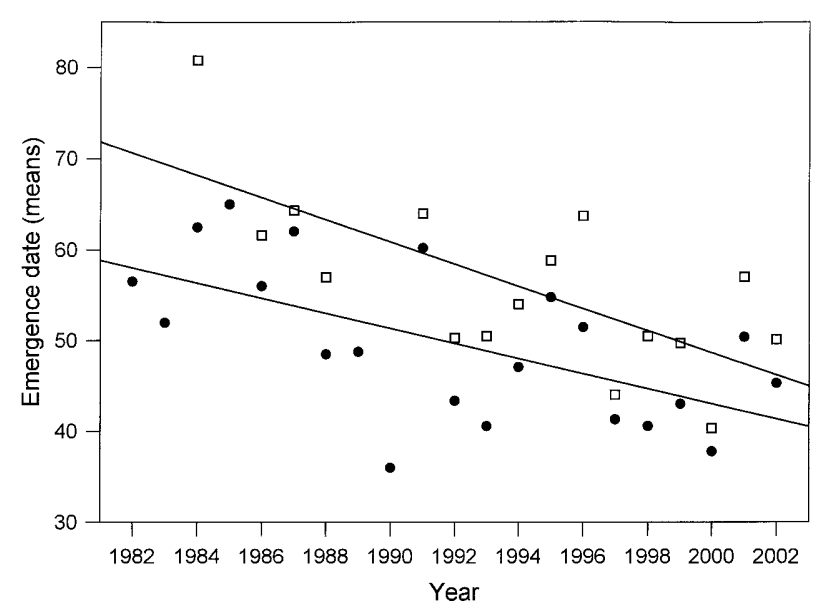

Fig. 1. Trend in mean emergence dates in Apatura iris (days after April 30) over the period 1982 to 2002. The two lines represent from bottom to top: mean emergence of males (solid circles) and mean emergence of females (squares). Males: $\mathrm{r}=$ $-0.64, \mathrm{P}=0.002$, females: $\mathrm{r}=-0.71, \mathrm{P}=0.002$.

emergent broods in five years (1982-83, 1985, 1989-90). Males are typically protandrous and emerged before females. Matched for years the mean difference $( \pm 1 \mathrm{SE})$ in days was significant (males $49.1 \pm 2.0$ days, females $56.0 \pm 2.4$ days; $\left.\mathrm{t}_{15}=-6.69, \mathrm{P}<0.001\right)$. First emergence date correlated highly with mean emergence date for both sexes (males $\mathrm{r}=0.98$, females $\mathrm{r}=0.94, \mathrm{P}<0.0001$ in both cases). Male and female emergence dates also correlated closely $(\mathrm{r}=0.91, \mathrm{P}<0.0001)$.

When matched for years, mean pupation date and mean emergence date correlated highly (males $r=0.95$, females $\mathrm{r}=0.97, \mathrm{P}<0.0001$ in both cases). The pupation period was partly influenced by pupation date. The earlier the pupation date for each individual, the longer the pupation period; this was significant in the females $(\mathrm{r}=-0.36, \mathrm{P}<$ $0.001)$ but not in the males $(\mathrm{r}=-0.10, \mathrm{P}=0.35)$.

Pupae were parasitised by Psilomastax pyramidalis Tischbein 1868 (Ichneumoninae) after 1993. The proportion of pupae parasitised increased with years (Gamma $=$ $0.78, \mathrm{P}=0.0006)$ in relation to the number of eggs and larvae collected $(\mathrm{Gamma}=0.58, \mathrm{P}=0.011)$ but not population density (Gamma $=-0.11, \mathrm{P}=0.65)$. The percentage of individual $A$. iris surviving increased with the number of larvae and eggs collected (Gamma 0.39, $\mathrm{P}=$ 0.018) and also increased, rather than decreasing as expected, with increased parasitism (Gamma 0.49, P = $0.03)$.

\section{Trends in $A$. iris phenology dates with time}

A significant linear trend was detected in mean adult emergence date with emergence becoming increasingly early (Fig. 1). No significant autocorrelation occurred in emergence date (Pearson's r, $\mathrm{P}=0.08$ to 0.63 ) and there was no significant trend in population abundance in wild colonies over years (density of early stages) $(\mathrm{r}=-0.10, \mathrm{P}$ $=0.69$ ). Time (year) accounted for $41 \%$ to $50 \%$ of the variation in emergence dates; over a decade, males emerged on average 9 days earlier and females over 12

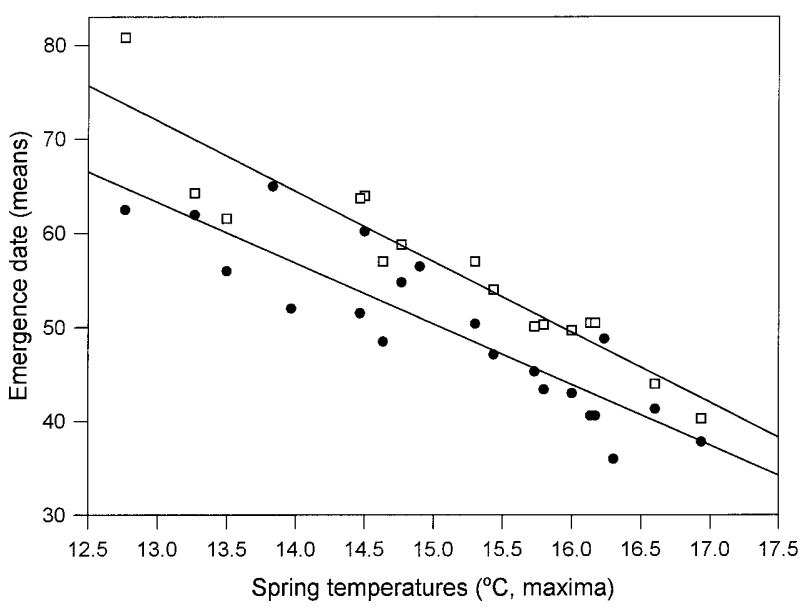

Fig. 2. Linear relationships of emergence dates (means, days after April 30) with spring temperatures (mean maximum temperatures for March to May). Lower line (solid circles): males, $r$ $=-0.90$. Upper line (squares): females, $\mathrm{r}=-0.94$.

days earlier. Although the difference of over 9.2 days between mean emergence date for the sexes in 1982 was reduced to only 3.8 days in 2002 , the difference in slopes was not significant $\left(\mathrm{t}_{33}=1.15, \mathrm{P}=0.26\right)$. During 2000 to 2002, three larvae continued to develop, rather than entering diapause, two surviving to adults in the autumns of 2001 and 2002, and in effect producing a second brood.

The timing of mean pupation dates advanced over time (males, $\mathrm{r}=-0.56, \mathrm{P}=0.009$; females, $\mathrm{r}=-0.77, \mathrm{P}=$ 0.001). But, pupal period did not change over time (years) (males, $\mathrm{r}=-0.01, \mathrm{P}=0.95$; females, $\mathrm{r}=0.36, \mathrm{P}=0.18$ ).

\section{Relationships of $\boldsymbol{A}$. iris phenology with temperatures}

Adult mean emergence date (sexes separately) was regressed (stepwise forwards entry) against maximum temperatures for the period of February to June in the current year and for July to October in the previous year. The regression included variables measuring population abundance (density, number of eggs and larvae collected/area searched) and sample size (number bred each year).

Population abundance (density) and sample size (number bred) had no influence on mean emergence date (Table 1). The regressions for both sexes were dominated by maximum temperatures for three months: March, April and May (Table 1, Fig. 2). In every case the regression coefficients were negative, indicating earlier emergence with higher maximum temperatures, and the variables accounted for $84 \%$ to $97 \%$ of the variation in emergence dates.

\section{Trends in temperatures over time}

During the 21 year period, annual temperatures significantly increased (annual mean temperatures: $\mathrm{r}=0.68, \mathrm{P}<$ $0.001,0.95^{\circ} \mathrm{C}$ per decade; annual maximum temperatures: $\mathrm{r}=0.59, \mathrm{P}=0.006,0.87^{\circ} \mathrm{C}$ per decade). Significant increases in temperatures occurred for only four months, for February, March, May and June (Table 2); April tem- 
TABLE 1. Stepwise regression parameters relating emergence dates in Apatura iris to monthly maximum temperatures ${ }^{1}$, population abundance and sampling size ${ }^{2}$. Cum $\mathrm{R}^{2}$ represents the cumulative $\mathrm{R}^{2}$ in the stepwise model. Parameters are reported only for significant variables entering the equations.

\begin{tabular}{|c|c|c|c|c|c|}
\hline \multicolumn{6}{|c|}{ Males: mean emergence date, $\mathrm{F}_{3,17}=29.65 \mathrm{P}<0.00001$} \\
\hline Step & Variable & $\mathrm{B}$ & $\mathrm{B}_{\mathrm{se}}$ & Cum $\mathrm{R}^{2}$ & $\mathrm{P}$ \\
\hline 1 & May & -2.72 & 0.44 & 54.1 & 0.0001 \\
\hline 2 & April & -2.34 & 0.48 & 71.4 & 0.004 \\
\hline 3 & March & -1.63 & 0.45 & 84.0 & 0.002 \\
\hline \multicolumn{6}{|c|}{ Females: mean emergence date, $\mathrm{F}_{3,12}=34.58 \mathrm{P}<0.00001$} \\
\hline Step & Variable & B & $\mathrm{B}_{\mathrm{se}}$ & Cum $\mathrm{R}^{2}$ & $\mathrm{P}$ \\
\hline 1 & May & -2.84 & 0.47 & 59.8 & 0.0004 \\
\hline 2 & April & -2.07 & 0.49 & 74.2 & 0.02 \\
\hline 3 & March & -2.13 & 0.50 & 89.6 & 0.001 \\
\hline
\end{tabular}

${ }^{1}$ Monthly temperatures entered for February to June of current year and July to October of previous year. Emergence dates are weighted by number of emergences in any year. ${ }^{2}$ Both population abundance (density) and sample size (number of individuals bred in each year) were entered into the equations to test for population size and sampling artefacts. Both failed to enter the equations, as did all other monthly temperatures.

peratures increased by $>0.5^{\circ} \mathrm{C}$ per decade but this was not significant.

\section{Trends and associations in $S$. caprea phenology}

Flowering dates in $S$. caprea advanced with years ( $\mathrm{r}=$ $-0.67, \mathrm{P}=0.0009), 14.4$ days earlier per decade between 1982 and 2002 occurring on average in late March in 1982 but in February in 2002. Maximum temperatures for the early part of the year (January to March) explained a significant proportion of the variation in flowering date $\left(\mathrm{F}_{3,17}=38.3, \mathrm{R}^{2}=87.2 \%, \mathrm{P}<0.00001\right)$. Day-time maximum temperatures provided a better relationship than mean monthly temperatures $\left(\mathrm{R}^{2}=78.8 \%\right)$.

$A$. iris mean emergence date correlated with $S$. caprea flowering date for males $(\mathrm{r}=0.55, \mathrm{P}=0.011)$ and females $(\mathrm{r}=0.54, \mathrm{P}=0.03)$. In a stepwise regression of $A$. iris emergence date on year and $S$. caprea flowering, only year is entered, a result occurring for both sexes. In a further stepwise regression of $A$. iris emergence date against monthly spring temperatures (March to May) and $S$. caprea flowering date, only temperatures were entered into the regression as in Table 1 . Flowering in $S$. caprea did not contribute significantly to the model (males $\mathrm{P}=$ 0.92; females $\mathrm{P}=0.64$ ).

\section{DISCUSSION}

\section{Factors in earlier emergence date of $\boldsymbol{A}$. iris}

The data on adult emergence date for $A$. iris from Basel, Switzerland from 1982 to 2002 reveal a systematic advance in emergence dates for the butterfly coinciding with an increase in temperatures over this period. The butterfly is emerging some 9 to 12 days earlier a decade for a rise in mean maximum temperatures of just under $1{ }^{\circ} \mathrm{C}$. No influence of population numbers, or of numbers of $A$. iris being bred, was found; that is, there is no evidence of artefacts of increasing population size or sam-
TABLE 2. Correlations of changes in air temperatures $\left({ }^{\circ} \mathrm{C}\right)$ with time (years) for Basel, Switzerland between 1982 and 2002.

\begin{tabular}{lccccccc}
\hline \multirow{2}{*}{ Month } & \multicolumn{3}{c}{ Mean temperatures } & & \multicolumn{3}{c}{ Maximum temperatures } \\
\cline { 2 - 3 } \cline { 7 - 8 } & $\mathrm{r}$ & $\mathrm{P}$ & $\begin{array}{c}\text { Change } \\
\left({ }^{\circ} \mathrm{C} / \text { decade }\right)\end{array}$ & $\mathrm{r}$ & $\mathrm{P}$ & $\begin{array}{c}\text { Change } \\
\left({ }^{\circ} \mathrm{C} / \text { decade }\right)\end{array}$ \\
\hline January & 0.17 & 0.46 & 0.76 & & 0.15 & 0.53 & 0.71 \\
February & 0.55 & 0.01 & 2.83 & & 0.51 & 0.02 & 3.04 \\
March & 0.50 & 0.03 & 1.71 & & 0.48 & 0.03 & 1.78 \\
April & 0.28 & 0.24 & 0.55 & & 0.24 & 0.30 & 0.69 \\
May & 0.53 & 0.02 & 1.65 & & 0.46 & 0.04 & 1.16 \\
June & 0.52 & 0.02 & 1.05 & & 0.48 & 0.03 & 1.16 \\
July & -0.19 & 0.42 & -0.45 & & -0.35 & 0.13 & -0.04 \\
August & 0.36 & 0.12 & 0.63 & & 0.15 & 0.53 & 0.31 \\
September & -0.08 & 0.75 & -0.24 & & -0.19 & 0.43 & -0.67 \\
October & 0.25 & 0.29 & 0.66 & & 0.09 & 0.72 & 0.30 \\
November & 0.06 & 0.81 & 0.20 & -0.06 & 0.80 & -0.23 \\
December & 0.02 & 0.92 & 0.07 & -0.02 & 0.92 & -0.07 \\
\hline
\end{tabular}

pling effects on emergence date (Thomas, 1985). The advance in emergence date correlates significantly with temperatures only for spring months (March to May). This is particularly interesting as it is the early months (February to June), with one exception, for which there is a significant increase in mean and maximum temperatures throughout the period; for day-time maximum temperatures this increase is of the order of $0.69^{\circ} \mathrm{C}$ to $1.87^{\circ} \mathrm{C}$ per decade. The exception is April that shows a nonsignificant rise in mean temperature of $0.55^{\circ} \mathrm{C}$ per decade (maximum temperature $0.69^{\circ} \mathrm{C}$ ).

The key months relating emergence timing with temperatures are March, April and May when the insect is in late larval stages and renewing activity and development after hibernation. It is noteworthy that by far the largest variation accounted for is by May temperatures, when day-time feeding is extending and growth rates are at a maximum. March and April, the period of bud burst and initial post hibernation growth, account for lower additional variation. There is no significant impact of the previous summer or autumn temperatures (when larvae feed before hibernation). Even though pupation date correlates strongly with emergence date, earlier emergence is not determined by any reduction in the pupation period. Underlying this apparent anomaly is the relationship between pupation period and date of pupation; individuals pupating earlier in the year remain as pupae for longer periods, a relationship that is significant for females. Thus, earlier or faster development in the larval stage will draw forward pupation to a cooler time of the spring; if the temperature difference between previous and current pupation dates is not offset by rising temperatures during the period 1982 to 2002, the pupal period will be extended.

Rising temperatures in spring may influence $A$. iris emergence dates in two, not exclusive, ways: through development timing and development rates. First, bud 
burst in $S$. caprea may be advanced with renewed feeding and development in $A$. iris occurring earlier. Second, the higher temperatures, especially day-time maximum temperatures when the larvae are feeding, may result in faster development rates. This can arise by the larvae feeding longer during each day or by more rapid ingestion (Dennis, 1993). The data on flowering in S. caprea in S. W. Germany strongly suggest there was seasonal advancement in $S$. caprea bud burst. Large scale consistency is reported in phenological changes (e.g., Menzel \& Fabian, 1999). This is supported by bud burst data from Switzerland (Swiss Phenological Observation Network) based on 40 stations and 69 phenophases of 26 different plant species, mainly wild plants; these data record an average advance of 11.6 days for significant photophases (Defila \& Clot, 2001). The correlation of $A$. iris with $S$. caprea flowering suggests that earlier bud burst in $S$. caprea may be partially responsible for seasonal advancement in $A$. iris emergence dates. But, three facts would indicate that the largest effect is on late larval instar growth and feeding period. First, May temperatures dominate emergence dates. Second, $S$. caprea flowering is excluded in stepwise regression models with temperatures and years. Third, the convergence of female with male emergence dates points to limits on earlier feeding in protandrous males; although this trend is not significant the mean difference in emergence dates has been halved over the period 1982-2002.

\section{Implications of advancement in eclosions for $\boldsymbol{A}$. iris}

Advancement in flight period has both potential advantages and disadvantages for the organism. For multivoltine species, there is the potential for increasing population size resulting from a higher intrinsic rate of increase (Pollard \& Yates, 1993). But, the production of a second brood in A. iris is fatal; individuals so produced, as from 2000, emerge in cold autumn conditions, unable to breed as leaf fall removes food for early instars. For characteristically univoltine species, such as $A$. iris, early appearance typically results in an extended flight period (a longer lower tail) and thus potential for risk spreading of early stages through seasonal weather conditions (but see Roy \& Sparks, 2000).

There is no evidence that populations of $A$. iris are increasing, as might be expected, in the woodland sourcing the specimens for this study. In fact, casual observations indicate that adult $A$. iris numbers have declined. The influences on population numbers may be local; forestry activities (e.g., coppicing) have reduced the numbers of $S$. caprea over the study period (Dell, pers. observ.). One possible artefact of climatic warming may be increased parasitism (Dennis, 1993). Parasitism of $A$. iris larvae by $P$. pyramidalis has indeed increased during the study period but as this correlates with the number of eggs and larvae being bred and not population density, this may simply occur as an artefact of sampling; this conclusion is supported by the positive rather than negative correlation of parasitism with percent individuals surviving during breeding. However, it should be mentioned that climatic warming may increase the susceptibility of
A. iris to enemies by advancing the pupation date. Increased mortality of pupae owing to a lengthening in the pupation period has been recorded in another closely related woodland butterfly Limenitis camilla (Pollard, 1979). A further consideration is that not all months have become warmer during this period. Gains at one stage in the year may be countered by cooler or damper conditions in July, when the butterfly is mating and egglaying, and in September when young larvae are first developing.

Just how far emergence date can be advanced depends crucially on the timing between bud burst and recommencing of feeding after hibernation. From feeding damage on unopened buds, A. iris is known to renew activity before bud burst, an observation repeated in this study (Dell, pers. observ.). Therefore, as in the case of synchrony between butterfly and crucifer hosts in Anthocharis cardamines Linnaeus (Sparks \& Yates, 1997), earlier bud burst should be matched by advancement in renewed activity in $A$. iris. If bud burst in $S$. caprea falls behind renewed activity in $A$. iris, then larvae will become food limited. Lack of synchrony has been observed in other species (e.g., Operophtera brumata (Linnaeus), Geometridae, with oak bud burst; cf., Buse \& Good, 1996 with Visser \& Holleman, 2001). There is indication from the German $S$. caprea flowering data that this is not a danger. Advancement in bud burst timing will also depend on genetic variation in temperature requirements for bud burst; this is relatively large in some Salix species (Lennartsson, 2003). It is interesting that although temperatures are rising fastest in late winter and early spring (February and March) the difference in emergence dates between the sexes is decreasing; males are protandrous but are not advancing in emergence dates as fast as females. This observation suggests a limit to emergence dates in males. Regardless of synchronization of herbivore and host, earlier bud burst is associated with a further threat from early frosts.

\section{Wider context of earlier emergence date in $A$. iris}

These findings for continental $A$. iris closely correspond to and support findings for shifts in phenology of other butterfly species in Britain and Spain. They support recent research findings that suggest timing of many natural events is occurring earlier in recent years and that climate is the most likely cause (e.g., Crick et al., 1997; Sparks \& Menzel, 2002). Specifically, there is widespread demonstration now that advances in eclosion and flight periods are associated with warmer springs (Sparks \& Carey, 1995; Sparks \& Yates, 1997; Roy \& Sparks, 2000; Stefanescu et al., 2003) and that eclosion dates and flight period timing are closely related (Brakefield, 1987) especially for univoltine species such as A. iris (Roy \& Sparks, 2000). Roy \& Sparks (2000) indicate that climate warming of the order of $1{ }^{\circ} \mathrm{C}$ could advance first and peak appearance of most butterflies by 2 to 10 days. It has been demonstrated that in line with projected climatic scenarios, a rise in temperatures of $3^{\circ} \mathrm{C}$ could advance butterfly appearance by two to three weeks (Sparks \& Yates, 1997). This is more than matched by advanced emergence dates in $A$. iris in Switzerland; males are already 
emerging 19 days and females 24 days earlier in 2002 than in 1982 for a rise in annual mean and maximum temperatures of $<2{ }^{\circ} \mathrm{C}$. There may still be potential for further advancement in timing as temperatures in February are rising most rapidly.

For almost all butterfly species studied there is a highly significant, negative, relationship between first appearance date and weather, i.e. warmer weather producing earlier first appearances (Roy \& Sparks, 2000). The advance in emergence timing for $A$. iris exceeds the fastest rate for univoltine species elsewhere (7.6 days/decade for $A$. cardamines and 5.3 days/decade for Gonepteryx rhamni) (Roy \& Sparks, 2000). These findings for $A$. iris are valuable then for demonstrating a wide impact of warmer springs throughout Western Europe on butterfly phenology including species dependent on arboreal host plants. The impact of climatic warming may be greater in continental locations as increasing warmth is less likely to be offset by variable spring weather from frontal systems along ocean margins. These findings are also unaffected by any autocorrelation among seasonal emergence date or by population abundance.

\section{CONCLUSIONS}

A strong trend towards earlier emergences in the nymphalid butterfly Apatura iris in Switzerland has been demonstrated; on average, they are emerging 19 (males) to 24 (females) days earlier in 2002 than in 1982. This pattern has been demonstrated to be strongly related to an increase in spring temperatures that are also shown to have been increasing during this period. The greater influence has been on later larval growth and development rather than on earlier renewal of larval feeding following hibernation. These findings reinforce the hypothesis that climate change has potential negative effects on the phenological appearance dates of phytophagous insects.

ACKNOWLEDGEMENTS. We thank Deutscher Wetterdienst for use of data on Salix caprea from south west Germany, for which they hold copyright. We also thank the MeteoSchweiz (Krähbühlstrasse 58, Postfach 514, CH-8044 Zürich, Switzerland) for access to their online database for climate data for Basel and D. Steiner, Institute of Geography, Meteorology and Climatology, University of Bern for assisting access. A. Menzel, Technical University of Munich, provided valuable information at the start of this project and M. Shaw, National Museums of Scotland, Edinburgh kindly identified Psilomastax pyramidalis. Our grateful thanks to four anonymous referees for their helpful comments on an earlier version of the paper.

\section{REFERENCES}

Archaux F. 2003: Birds and climate change. Vie Milieu 53 $33-41$.

Asher J., Warren M., Fox R., Harding P., Jeffcoate G. \& JefFCOATE S. 2001: The Millennium Atlas of Butterflies in Britain and Ireland. Oxford University Press, Oxford, $433 \mathrm{pp}$.

BRAKEFIELD P.M. 1987: Geographical variability in, and temperature effects on, the phenology of Maniola jurtina (Lepidoptera, Satyridae) in England and Wales. Ecol. Entomol. 12: 139-148.
Buse A. \& Good J.E. 1996: Synchronization of larval emergence in winter moth (Operophtera brumata L.) and bud burst in pedunculate oak (Quercus robur L.) under simulated climate change. Ecol. Entomol. 21: 335-343.

Coppack T. \& Bотн C. 2002: Predicting life-cycle adaptation of migratory birds to global climate change. Ardea 90: 369-378.

CоLомво S.J. 1998: Climatic warming and its effect on bud burst and risk of frost damage to white spruce in Canada. For. Chron. 74: 567-577.

CotTon P.A. 2003: Avian migration phenology and global climate change. Proc. Natl. Acad. Sci. USA 100: 12219-12222.

Crick H.Q.P., Dudley C., Glue D.E. \& Thomson D.L. 1997: UK birds are laying eggs earlier. Nature 388: 526.

Defila C. \& Clot B. 2001: Phytophenological trends in Switzerland. Int. J. Biometeorol. 45: 203-207.

Dennis R.L.H. 1993: Butterflies and Climate Change. Manchester University Press, Manchester, 302 pp.

Draper N.R. \& SMith H. 1981: Applied Regression Analysis. Wiley, London, $407 \mathrm{pp}$.

Dullinger S., Dirnbock T. \& Grabherr G. 2004: Modelling climate change-driven treeline shifts: relative effects of temperature increase, dispersal and invisibility. J. Ecol. 92: 241-252.

FitTer A.H., Fitter R.S.R., Harris I.T.B. \& Williamson M.H. 1995: Relationship between first flowering date and temperature in the flora of a locality in central England. Funct. Ecol. 9: $55-60$.

Georges J.Y. \& Le Maho Y. 2003: Responses of marine and insular ecosystems to climate change. C.R. Geosci. 335: 551-560.

GoOdMAN L.A. \& KRUSKAL W.H. 1972: Measures of association for cross-classifications. IV. Simplification of asymptotic variances. J. Am. Stats. Assoc. 67: 415-421.

Harrington R., Woiwod I. \& Sparks T.H. 1999: Climate change and trophic interactions. Trends Ecol. Evol. 14: 146-149.

Heslop I.R.P., Hyde G.E. \& Stockley R.E. 1964: Notes and Views on the Purple Emperor. The Southern Publishing Company, Brighton, $248 \mathrm{pp}$.

Higgins S.I., Clark J.S., Nathan R., Hovestadt T., Schurr F., Fragoso J.M.V., Aguiar M.R., Ribbens E. \& Lavorel S. 2003: Forecasting plant migration rates: managing uncertainty for risk assessment. J. Ecol. 91: 341-347.

Hill J.K., Thomas C.D. \& Huntley B. 1999: Climate change and habitat availability determine $20^{\text {th }}$ century changes in a butterfly's range margin. Proc. R. Soc. Lond. (B) 266: $1197-1206$.

Houghton J.T., Meira Filho L.G., Callander B.A., Harris N., Kattenberg A. \& Maskell K. 1996: Climate Change 1995: The Science of Climatic Change. Cambridge University Press, Cambridge, 572 pp.

JENNI L. \& KeRY M. 2003: Timing of autumn bird migration under climate change: advances in long-distance migrants, delays in short-distance migrants. Proc. R. Soc. Lond. (B) 270: $1467-1471$.

Johnstone J.F. \& Chapin F.S. 2003: Non-equilibrium succession dynamics indicate continued northern migration of lodgepole pine. Glob. Change Biol. 9: 1401-1409.

LeCHowicz M.J. 1995: Seasonality of flowering and fruiting in temperate forest trees. Can. J. Bot. 73: 175-182.

Lemoine N. \& Bohning-Gaese K. 2003: Potential impact of global climate change on species richness of long-distance migrants. Conserv. Biol. 17: 577-586.

Lennartsson M. 2003: Cold Hardening and Dehardening in Salix. Ph.D. Thesis, Acta universitatis agriculturae Sueciae, Silvestria 279, Swedish University of Agricultural Sciences, Umeå, $39 \mathrm{pp}$. 
Malcolm J.R., Markham A., Neilson R.P. \& Garaci M. 2002: Estimated migration rates under scenarios of global climate change. J. Biogeogr. 29: 835-849.

Menzel A. \& Fabian P. 1999: Growing season extended in Europe. Nature 397: 659.

Parmesan C., Ryrholm N., Stefanescu C., Hill J.K., Thomas C.D., Descimon H., Huntley B., Kaila L., Kullberg J., Tammaru T., Tennent J., Thomas J.A. \& Warren M.S. 1999: Poleward shifts in geographical ranges of butterfly species associated with regional warming. Nature 399: 579-583.

Pearson R.G. \& Dawson T.P. 2003: Predicting the impacts of climate change on the distribution of species: are bioclimate envelope models useful? Glob. Ecol. Biogeogr. 12: 361-371.

Pollard E. 1979: Population ecology and change in range of the white admiral butterfly Ladoga camilla L. in England. Ecol. Entomol. 4: 61-74.

PollaRd E. 1988: Temperature, rainfall and butterfly numbers. J. Appl. Ecol. 25: 819-828.

Pollard E. \& Yates T.J. 1993: Monitoring Butterflies for Ecology and Conservation. Chapman \& Hall, London, 288 pp.

Roy D.B. \& Sparks T.H. 2000: Phenology of British butterflies and climatic change. Glob. Change Biol. 6: 407-416.

Skre O., Baxter R., Crawford R.M.M., Callaghan T.V. \& FEDORKov A. 2002: How will the tundra-taiga interface respond to climate change? Ambio 12: 37- 46.

Sparks T.H. \& CAREY P.D. 1995: The responses of species to climate over two centuries: An analysis of the Marsham phenological record, 1736-1947. J. Ecol. 83: 321-329.
Sparks T.H. \& Menzel A. 2002: Observed changes in seasons: an overview. Int. J. Climatol. 22: 1715-1725.

SpARKS T.H. \& YATES T.J. 1997: The effect of spring temperature on the appearance dates of British butterflies 1883-1993. Ecography 20: 368-374.

Statsoft 1999: STATISTICA for Windows 95/98/NT. Tulsa, OK. Stefanescu C., Peñuelas J. \& Filella I. 2003: Effects of climatic change on the phenology of butterflies in the north west Mediterranean Basin. Glob. Change Biol. 9: 1494-1506.

SwaAy C. van \& Warren M.S. 1999: Red Data Book of European Butterflies (Rhopalocera). Nature and Environment No. 99. Council of Europe Publishing, Strasbourg.

Thомаs C.D. 1985: Specializations and polyphagy of Plebejus argus (Lepidoptera: Lycaenidae) in North Wales. Ecol. Entomol. 10: $325-340$

Travis J.M.J. 2003: Climate change and habitat destruction: a deadly anthropogenic cocktail. Proc. R. Soc. Lond. (B) 270: 467-473.

VisSer M.E. \& Holleman L.J.M. 2001: Warmer springs disrupt the synchrony of oak and winter moth phenology. Proc. $R$. Soc. Lond. (B) 268: 289-294.

Willmott K.J. 1990: Apatura iris (Linnaeus). The Purple Emperor. In Emmet A.M. \& Heath J. (eds): The Butterflies of Great Britain and Ireland. Harley Books, Colchester, pp. 186-189.

Received August 12, 2004; revised and accepted January 21, 2005 